\title{
Skroplony gaz ziemny - LNG. Część I - Zagadnienia ogólne i podstawy procesu rozliczeniowego
}

\begin{abstract}
W niniejszym artykule przedstawiono ogólną charakterystykę fizykochemiczną skroplonego gazu ziemnego LNG, jak również ogólne metody rozliczeń i kontroli jakości LNG w morskich terminalach załadowczych i odbiorowych. Omówiono wszystkie rodzaje pomiarów dotyczących rozliczeń LNG wykonywanych na lądzie i na statku. Przybliżono również historię rozwoju światowego handlu LNG oraz stan aktualny. Niniejszy artykuł jest pierwszym z planowanej serii artykułów dotyczących technicznych aspektów związanych z oczyszczaniem i skraplaniem gazów, pomiarami w procesie rozliczeniowym LNG i kontrolą jakości LNG.
\end{abstract}

Słowa kluczowe: LNG, proces rozliczeniowy, skraplanie gazu, regazyfikacja.

\section{Liquefied natural gas - LNG. Part I - General issues and basis of LNG custody transfer}

In this article a general physico-chemical profile of LNG is presented as well as general custody transfer and quality control methods related to LNG in loading and unloading sea-terminals. There are also presented all types of measurements related to LNG custody transfer made on land and on the vessel, the history of world LNG trade and contemporary status of LNG trade. This article is the first one in a series of planned articles related to: purification, liquification, measurements in custody transfer of LNG, and quality control of LNG.

Key words: LNG, custody transfer, gas liquefaction, regasification.

\section{Wstęp}

Powszechnie stosowana i popularna nazwa LNG pochodzi od skrótu z angielskiego wyrażenia liquefied natural gas, co w thumaczeniu na język polski oznacza „skroplony gaz ziemny". Patrząc z historycznego punktu widzenia, według portalu edukacyjnego www.lng.edu.pl [1], pierwszego skroplenia gazu ziemnego, czyli przekształcenia tego gazu w fazę ciekłą, dokonał najprawdopodobniej angielski fizyk i chemik Michael Faraday (1791-1867). Późniejsze prace dwóch profesorów Uniwersytetu Jagiellońskiego w Krakowie Zygmunta Wróblewskiego (1845-1888) i Karola Olszewskiego (1848-1915), którym udało się w 1883 roku skroplić tlen (5 kwietnia) i azot (13 kwietnia) z powietrza atmosferycznego, położyły bardzo istotne podwaliny pod opracowanie procesu skraplania gazów. Metoda zastosowana przez Wróblewskiego i Olszewskiego - tzw. metoda kaskadowa - do dziś jest powszechna przy skraplaniu gazów. Kolejnych podstaw dostarczyły prace niemieckiego inżyniera-przedsiębiorcy Karla P. Gottfrieda von Lindego (1842-1934), założyciela istniejącego do dziś koncernu Linde AG, który zbudował pierwszą w świecie instalację schładzającą (1873), a w 1896 roku opatentował technologię schładzania i skraplania gazów.

Pomimo że pierwsza eksperymentalna instalacja do schładzania i skraplania gazu ziemnego powstała stosunkowo dawno temu, bo w 1917 roku w USA, w stanie Wirginia Zachodnia, a pierwszą komercyjną instalację do skraplania LNG wybudowano w Cleveland w stanie Ohio w USA w 1941 roku, to światowy handel skroplonym gazem ziemnym rozpoczął się dopiero kilkanaście lat po II wojnie światowej. Wiązało się to z okresem wzrostu zapotrzebowania świata i odrodzonej po wojnie Europy na duże ilości energii. Na początku 1959 roku odbył się pierwszy komercyjny transport LNG drogą morską. 
Wtedy to statek ,The Methane Pioneer”, który został przerobiony na gazowiec z transportowca używanego podczas II wojny światowej do celów typowo militarnych, przewiózł pierwszy ładunek LNG z Lake Charles w stanie Luizjana w USA do Canvey Island w Wielkiej Brytanii. W kolejnych latach oprócz dostaw LNG do Wielkiej Brytanii z USA doszły jeszcze transporty z Wenezueli. Przewóz skroplonego gazu przez Atlantyk miał jednak jeden mankament - drogi transportowe były długie. Po odkryciu na początku lat 60 . XX wieku złóż gazu ziemnego w Libii i Algierii w Afryce Północnej zaczął dominować jednak ten kierunek dostaw do Europy. W 1964 roku dokonano pierwszej dostawy LNG na rynek brytyjski z Algierii, która wkrótce stała się największym eksporterem gazu skroplonego na świecie [1].

Okres przełomu lat 60. i 70. XX wieku to także czas rozbudowy połączeń gazociągowych pomiędzy Europą i Afryką Północną i przede wszystkim okres prosperity w wydobyciu gazu i rozbudowie infrastruktury gazowej na Morzu Północnym oraz początek zasilania Europy Środkowo-Wschodniej w gaz ziemny z kierunku ówczesnego Związku Radzieckiego. Te wydarzenia pozornie ograniczyły rozwój handlu LNG w obszarze europejskim. W latach 70. i 80. koniunkturę dla LNG kreowały jednak kraje Dalekiego Wschodu, głównie Japonia i Korea Południowa, które do dziś są największymi importerami LNG na świecie (Japonia: 88 MTPA, Korea Południowa: 45 MTPA [6]).

O współczesnej roli i znaczeniu LNG świadczą liczby. Na koniec 2013 roku na świecie funkcjonowało 97 terminali regazyfikacyjnych i 25 terminali skraplających, z czego [5]:

- w Europie - 19 terminali regazyfikacyjnych i 1 terminal skraplający, bez uwzględniania terminala w Świnoujściu,

- w Azji, Oceanii i Australii - 29 terminali regazyfikacyjnych, z czego 26 w samej Japonii, oraz 16 terminali skraplających,

- w Afryce - 5 terminali skraplających,

- w Ameryce Północnej - 13 terminali regazyfikacyjnych i 1 terminal skraplający,

- w Ameryce Południowej - 10 terminali regazyfikacyjnych i 2 terminale skraplające.

W 2013 roku światowa flota statków transportowych LNG liczyła 392 jednostki [5], z których najmniejszy statek miał pojemność $2500 \mathrm{~m}^{3}$, a największy $267335 \mathrm{~m}^{3}$. Statki te były wodowane w latach 1969-2013, przy czym w samym tylko 2013 roku zwodowano aż 20 z nich. Największa liczba zwodowanych statków przypada na rok 2008 - 52 jednostki. Największą liczbę statków transportowych we współczesnej flocie transportowej stanowią statki z komorami ładunkowymi typu sferycznego o pojemności około $150000 \mathrm{~m}^{3}$. Są one stopniowo wypierane przez większe jednostki typu membranowego. W użyciu są także jednostki starsze typu IMO typ C o pojemnościach od $1000 \mathrm{~m}^{3}$ do $12000 \mathrm{~m}^{3}$, które stosuje się do małej żeglugi przybrzeżnej [11].

Większość światowych złóż gazu ziemnego jest położona daleko od miejsc jego użytkowania. Transport gazu ziemnego z obszarów wydobycia do miejsc wykorzystania stanowi bardzo istotny problem. Istotą handlu LNG jest możliwość jego transportu na bardzo duże odległości bez konieczności stosowania do tego celu gazociągów i wszelkiej liniowej infrastruktury przesyłowej z tym związanej (np. tłocznie gazu, podziemne magazyny gazu itp.). Oczywiście konieczna jest do tego inna infrastruktura, jak: terminale skraplania, terminale odbiorowe, flota gazowców, instalacje regazyfikacji, instalacje związane z przebunkrowywaniem LNG. Schematyczny łańcuch obrotu i wykorzystania LNG transportowanego drogami morskimi przedstawiono na rysunku 1 .

Zgodnie z danymi amerykańskiego Gas Technology Institute transport LNG drogą morską jest bardziej opłacalny w porównaniu z przesyłem ekwiwalentnej ilości gazu gazociągami podmorskimi już powyżej 1300 km, a w stosunku do transportu gazociągami lądowymi - powyżej $4000 \mathrm{~km}$ [2]. Generalnie skraplanie gazu ziemnego jest więc ekonomicznie opłacalne, jeżeli duże ilości LNG mogą być transportowane na znaczne odległości. 
Dla wciąż rosnącego światowego rynku LNG bardzo duże znaczenie ma lokalizacja złóż gazu ziemnego. Do głównych producentów, a zarazem eksporterów LNG należą kraje Bliskiego Wschodu, Ameryki Północnej i Południowej oraz Dalekiego Wschodu. Obecnie główne kierunki transportu LNG na świecie to [1]:

- z Bliskiego Wschodu, środkowo-wschodniej i północnej Afryki, Trynidadu i Tobago do wschodnich wybrzeży Ameryki Północnej oraz wysp Morza Karaibskiego. Żegluga odbywa się szlakami przebiegającymi przez Ocean Indyjski oraz Ocean Atlantycki. Znaczny wzrost wydobycia gazu ziemnego z tzw. złóż niekonwencjonalnych w Ameryce Północnej bardzo istotnie ograniczył po roku 2000 import gazu w postaci LNG w ten obszar świata;

- ze środkowo-wschodniej i północnej Afryki oraz Bliskiego Wschodu przez Morze Śródziemne i Atlantyk do krajów Europy Zachodniej i Południowej;

- z Bliskiego Wschodu, Archipelagu Malajskiego, Australii do wysoko uprzemysłowionych państw Dalekiego Wschodu poprzez Ocean Indyjski, morza Azji Południowo-Wschodniej;

- z Alaski do Japonii - żegluga odbywa się szlakami przebiegającymi przez Ocean Spokojny.

Plany zwiększenia eksportu LNG przez Stany Zjednoczone, Kanadę oraz Australię mogą w latach 2015-2025 zmienić wymienione powyżej główne kierunki transportu LNG.

Wytworzenie skroplonego gazu ziemnego polega na szeroko pojętym oczyszczeniu „surowego” gazu ziemnego - usunięciu pyłów, gazoliny, frakcji LPG, ewentualnych związków rtęci i siarki, osuszeniu - oraz na obniżeniu jego temperatury poniżej punktu wrzenia, czyli zwykle poniżej $-162^{\circ} \mathrm{C}$. Zmiana stanu skupienia powoduje zmniejszenie objętości LNG względem gazu pod normalnym ciśnieniem o około 600 razy. Pozwala to na efektywne przechowywanie paliw w stosunkowo ograniczonych objętościowo zbiornikach i transport gazu ziemnego w postaci LNG na bardzo duże odległości bez konieczności posiadania sieci gazociągowych.

Do transportu morskiego i przechowywania LNG wykorzystywane są duże zbiorniki kriogeniczne, izolowane od termicznego wpływu otoczenia, w których nadciśnienie fazy gazowej jest rzędu 0,5 bar. Do transportu lądowego oraz w instalacjach zasilania paliwowego stosuje się zbiorniki izolowane próżniowo, w których ciśnienie fazy gazowej mieści się zwykle w zakresie $3 \div 10$ bar.

LNG, z uwagi na skład chemiczny i stan skupienia, wykorzystuje się:

- do transportu gazu na bardzo duże odległości - transport statkami gazowcami oraz cysternami kolejowymi i samochodowymi,

- jako dogodną formę magazynowania energii (paliwa),

- do pokrywania szczytowego zapotrzebowania na energię (głównie w wydzielonych obszarach),

- jako paliwo do pojazdów oraz paliwo żeglugowe; ze względów bezpieczeństwa LNG nie jest powszechnie wykorzystywanym paliwem lotniczym,

- jako zagęszczone źródło surowca dla przemysłu chemicznego,

- jako źródło „,chłodu” w połączeniu z innymi funkcjami głównymi magazynowanego LNG.

\section{Właściwości LNG}

Skroplony gaz ziemny jest cieczą, która łatwo przechodzi w stan pary. Właściwości fizykochemiczne LNG zależą od jego składu chemicznego. W tablicy 1 podano przykładowe zestawienie wartości liczbowych odnoszących się do typowych właściwości skroplonego gazu ziemnego (na podst. [8]).
Tablica 1. Podstawowe właściwości fizykochemiczne LNG

\begin{tabular}{|l|c|}
\hline \multicolumn{1}{|c|}{ Właściwość } & \\
\hline Masa cząsteczkowa [a.j.m.] & 16,4 \\
\hline Temperatura skraplania $\left[{ }^{\circ} \mathrm{C}\right]$ (przy $p=1$ bar) & -161 \\
\hline Gęstość $\left[\mathrm{kg} / \mathrm{m}^{3}\right]$ (dotyczy cieczy) & $410 \div 470^{1)}$ \\
\hline Zapach & bezwonny \\
\hline Kolor & bezbarwny \\
\hline Temperatura zmętnienia $\left[{ }^{\circ} \mathrm{C}\right](\operatorname{przy} p=1$ bar) & $-187^{2)}$ \\
\hline Temperatura samozapłonu $\left[{ }^{\circ} \mathrm{C}\right](\operatorname{przy} p=1$ bar) & $540 \div 580$ \\
\hline Toksyczność & nietoksyczny \\
\hline Korozyjność & niekorozyjny \\
\hline Kancerogenność & nie stwierdzono \\
\hline Granice palności par w powietrzu $[\%$ obj.] & $5 \div 15^{3)}$ \\
\hline Rozpuszczalność w wodzie & bardzo słaba \\
\hline
\end{tabular}

${ }^{1)}$ Gęstość jest zależna od składu chemicznego.

${ }^{2)}$ Wartość przybliżona (orientacyjna), która w rzeczywistości zależy od składu LNG i jego potencjalnych zanieczyszczeń.

${ }^{3)}$ Granice zgrubne, które w rzeczywistości zależą od składu gazu. 


\section{Charakterystyka jakościowa LNG na świecie}

W zależności od składu gazu surowego oraz od zastosowa- może nieznacznie się różnić. W tablicy 2 podano przykładonej metody skraplania jakość LNG z poszczególnych źródeł we charakterystyki jakościowe LNG na świecie [4].

Tablica 2. Charakterystyka jakościowa LNG na świecie (na podstawie [4]; nazwy terminali skraplania pozostawione w zapisie angielskojęzycznym, zgodnie z [4])

\begin{tabular}{|c|c|c|c|c|c|c|c|c|c|c|}
\hline \multicolumn{8}{|c|}{ Dane według raportu [4] - Raport The LNG industry, GIIGNL, 2010} & \multicolumn{3}{|c|}{$\begin{array}{c}\mathrm{Z} \text { powodu błędów w raporcie } \\
\text { [4] poniższe dane zostały przeli- } \\
\text { czone dla warunków odniesienia } \\
25^{\circ} \mathrm{C} / 0^{\circ} \mathrm{C} / 101,325 \mathrm{kPa}^{3)}\end{array}$} \\
\hline $\begin{array}{c}\text { Terminal } \\
\text { skraplania }\end{array}$ & $\begin{array}{c}\text { Azot } \\
\mathrm{N}_{2} \\
{[\% \mathrm{~mol} .]}\end{array}$ & $\begin{array}{c}\text { Metan } \\
\mathrm{C}_{1} \\
{[\% \mathrm{~mol} .]}\end{array}$ & $\begin{array}{c}\text { Etan } \\
\mathrm{C}_{2} \\
{[\% \mathrm{~mol} .]}\end{array}$ & $\begin{array}{c}\text { Propan } \\
\mathrm{C}_{3} \\
{[\% \mathrm{~mol} .]}\end{array}$ & $\begin{array}{c}\text { Grupa } \\
\mathrm{C}_{4+} \\
{[\% \text { mol. }]}\end{array}$ & $\begin{array}{l}\text { Gęstość } \\
\text { LNG } \\
{\left[\mathrm{kg} / \mathrm{m}^{3}\right]}\end{array}$ & $\begin{array}{l}\text { Współ- } \\
\text { czynnik } \\
\text { ekspansji }{ }^{1)} \\
{\left[\mathrm{m}^{3} / \mathrm{m}^{3} \mathrm{liq}\right]}\end{array}$ & $\begin{array}{l}\text { Gęstość } \\
\text { gazu po re- } \\
\text { gazyfikacji } \\
{\left[\mathrm{kg} / \mathrm{m}^{3}\right]}\end{array}$ & $\begin{array}{l}\text { Ciepło } \\
\text { spalania } \\
{\left[\mathrm{MJ} / \mathrm{m}^{3}\right]}\end{array}$ & $\begin{array}{c}\text { Górna } \\
\text { liczba } \\
\text { Wobbego } \\
{\left[\mathrm{MJ} / \mathrm{m}^{3}\right]}\end{array}$ \\
\hline Algieria - Arzew & 0,6 & 88,0 & 9,0 & 2,0 & 0,5 & 464 & 570 & 0,813 & 44,0 & 55,5 \\
\hline Algieria - Bethioua 1 & 0,9 & 88,1 & 8,4 & 2,0 & 0,7 & 455 & 573 & 0,815 & 43,9 & 55,3 \\
\hline Algieria - Bethioua 2 & 0,6 & 90,7 & 7,8 & 0,8 & 0,0 & 450 & 577 & 0,779 & 42,4 & 54,6 \\
\hline Algieria - Skikda & 0,5 & 91,8 & 6,9 & 0,9 & 0,1 & 446 & 580 & 0,778 & 42,4 & 54,7 \\
\hline Egipt - Damietta & 0,1 & 97,7 & 1,8 & 0,22 & 0,2 & 427 & 585 & 0,736 & 40,7 & 53,9 \\
\hline Egipt - Idku & 0,0 & 95,9 & 2,8 & 0,9 & 0,5 & 436 & 579 & 0,757 & 41,7 & 54,5 \\
\hline Gwinea Równikowa & 0,0 & 93,4 & 6,5 & 0,0 & 0,0 & 439 & 585 & 0,758 & 41,8 & 54,5 \\
\hline Libia & 0,7 & 81,6 & 13,4 & 3,7 & 0,7 & 485 & 559 & 0,867 & 46,5 & 56,8 \\
\hline Nigeria & 0,1 & 92,1 & 5,3 & 2,1 & 0,5 & 458 & 566 & 0,788 & 43,1 & 55,2 \\
\hline Norwegia & 0,8 & 91,8 & 5,7 & 1,3 & 0,4 & 451 & 577 & 0,782 & 42,4 & 54,5 \\
\hline Trynidad i Tobago & 0,0 & 97,1 & 2,5 & 0,2 & 0,1 & 429 & 590 & 0,737 & 40,8 & 54,0 \\
\hline Abu Dhabi & 0,3 & 84,8 & 13,2 & 1,6 & 0,1 & 467 & 566 & 0,825 & 44,7 & 56,0 \\
\hline Oman & 0,4 & 87,9 & 7,3 & 2,9 & 1,6 & 470 & 563 & 0,833 & 45,1 & 56,1 \\
\hline Katar & 0,4 & 90,1 & 6,2 & 2,3 & 1,0 & 460 & 569 & 0,807 & 43,8 & 55,5 \\
\hline Jemen & 0,0 & 93,3 & 5,7 & 0,9 & 0,1 & 434 & 567 & 0,767 & 42,2 & 54,8 \\
\hline USA - Alaska & 0,2 & 99,7 & 0,1 & 0,0 & 0,0 & 423 & 589 & 0,719 & 39,8 & 53,3 \\
\hline Australia & 0,1 & 87,4 & 8,3 & 3,4 & 0,8 & 467 & 562 & 0,829 & 45,0 & 56,3 \\
\hline Brunei & 0,1 & 90,6 & 5,0 & 2,9 & 1,5 & 461 & 564 & 0,815 & 44,4 & 55,9 \\
\hline Indonezja - Arum & 0,2 & 90,7 & 6,2 & 2,0 & 1,0 & 457 & 569 & 0,803 & 43,8 & 55,5 \\
\hline Indonezja - Badak & 0,0 & 91,2 & 5,5 & 2,4 & 0,9 & 456 & 568 & 0,800 & 43,7 & 55,6 \\
\hline Indonezja - Tangguh & $? !^{2)}$ & $? !^{2)}$ & 2,9 & 0,5 & 0,2 & 432 & 580 & - & - & - \\
\hline Malezja & 0,3 & 90,3 & 5,3 & 3,1 & 1,1 & 461 & 567 & 0,813 & 44,2 & 55,7 \\
\hline Rosja - Sakhalin & 0,1 & 92,6 & 4,5 & 1,9 & 0,2 & 449 & 570 & 0,769 & 42,2 & 54,7 \\
\hline Peru & 0,6 & 89,1 & 10,3 & 0,1 & 0,0 & 456 & 579 & 0,788 & 42,8 & 54,8 \\
\hline
\end{tabular}

1) Oznacza stopień zagęszczenia objętości gazu po skropleniu (wg [4]).

2) Symbolem ,?!"” zaznaczono pozycje w tablicy, dla których nie podano wartości liczbowych w raporcie [4].

${ }^{3)}$ Warunki odniesienia obowiązujące w Polsce wg rozporządzenia Ministra Gospodarki z dnia 2 lipca 2010 r. w sprawie szczegółowych warunków funkcjonowania systemu gazowego (Dz. U. Nr 133, poz. 891) [12]; w oryginale w raporcie [4] niektóre wartości wyliczanych wielkości fizykochemicznych - gęstości po regazyfikacji, ciepła spalania i liczb Wobbego - dla przyjętych w nim warunków odniesienia były błędnie wyliczone.

\section{Pomiary rozliczeniowe LNG}

Rozliczenie ładunków LNG przewożonych drogą morską za pomocą statków transportowych zwanych gazowcami odbywa się od dawna na całym świecie w jednostkach energii.
Cały system rozliczeń prowadzony w terminalach rozładunkowych polega na pomiarach wielu wartości pośrednich, z których wyliczana jest finalna wartość energii „zmagazynowanej” 
w rozładowanej ilości LNG traktowanego jako paliwo. Istota pomiaru polega na dokładnej ocenie efektywnej objętości danej partii LNG i wyznaczeniu jej wartości kalorycznej. Iloczyn obydwu wielkości daje finalną wartość energii. Część pomiarów jest dokonywana na statku, a część na instalacjach lądowych terminali. Cykl systemu przeniesienia ładunku i pomiarów rozliczeniowych partii LNG rozładowywanej z gazowca do zbiorników lądowych terminali odbiorowych opisano poniżej i przedstawiono schematycznie na rysunku 2.

Pomiary dokonywane na statku:

a) pomiar poziomu cieczy LNG w komorze ładunkowej statku - przed rozpoczęciem rozładunku i po jego zakończeniu,

b) pomiar ciśnienia fazy gazowej nad cieczą w komorze ładunkowej statku,

c) pomiar temperatury LNG w komorze ładunkowej statku,

d) pomiar temperatury fazy gazowej nad cieczą w komorze ładunkowej statku.

Pomiary (analiza chemiczna) na lądzie:

a) analiza próbki LNG włącznie z procesem próbkowania analizy są zwykle wykonywane w zakresie jakościowym $\mathrm{C}_{1}-\mathrm{C}_{6+}, \mathrm{N}_{2}$ i $\mathrm{CO}_{2}$, choć w praktyce dla ładunków LNG transportowanych drogą morską składniki węglowodorowe powyżej $\mathrm{C}_{4}$ nie występują, podobnie jak i ditlenek węgla; kontrola jakości LNG jest jedynym ,pomiarem” wykonywanym na części lądowej terminali.

\section{Obliczenia na podstawie pomiarów:}

a) obliczenie ilości LNG w każdej komorze ładunkowej statku poprzez zmierzenie różnicy wysokości cieczy LNG w komorze przed rozpoczęciem i po zakończeniu rozładunku; w celu poprawnego przyporządkowania wysokości słupa LNG do objętości LNG w komorze ładunkowej korzysta się tutaj z tzw. tablic korekcyjnych statku, uwzględniających jego przechył wzdłuż głównej osi kadłuba (tzw. list) i różnicę zanurzenia rufy i dziobu statku wynikającą z chwilowego przebalastowania statku (tzw. trym), oraz z wszelkiego typu tabel temperaturowych współczynników korekcyjnych wpływających na rozszerzalność/kurczliwość termiczno-kriogeniczną elementów stalowych oraz na wyporność w cieczy LNG elementów pływakowych,

b) obliczenie objętości oparów gazu BOG, które wypełniają przestrzeń w komorze ładunkowej statku po wypom-
BOG

LNG (do sieci)

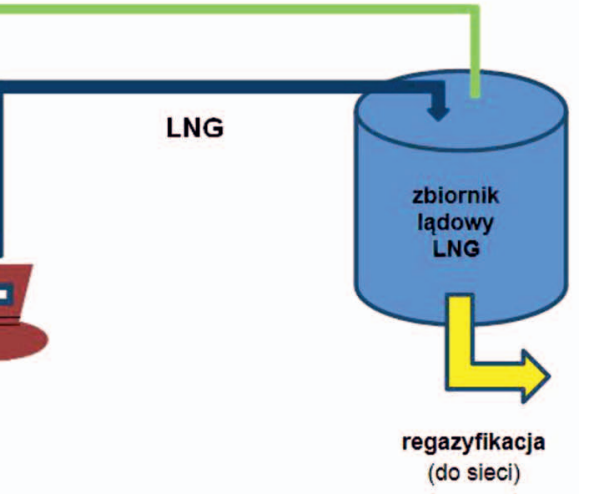

transportowy

(gazowiec)

LNG

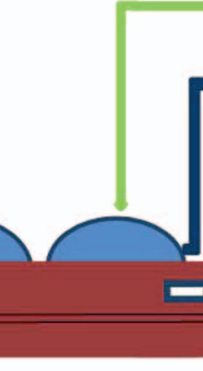
ów now ądowych do komór statku przy ich opróżnianiu z LNG) powaniu z niej LNG do zbiorników lądowych na terminalu - objętość wprowadzonego BOG i objętość wyładowanego LNG są sobie równe,

c) obliczenie gęstości LNG - według algorytmu ISO 6578 [9],

d) obliczenie ciepła spalania gazu wypełniającego BOG według algorytmu ISO 6976 [10],

e) obliczenie ciepła spalania LNG - według algorytmu [9],

f) obliczenie finalnej wartości energii rozładowanej partii LNG traktowanej jako paliwo - według równania (1) poniżej [3].

$$
E=\left(V_{L N G} \cdot D_{L N G} \cdot G C V_{L N G}\right)-E_{\text {Gas displaced }}-E_{G a s \text { to } E R}
$$

gdzie:

$E$ - całkowita energia „netto” pomniejszona o część energii „przeniesionej” w postaci BOG ( $\left.E_{\text {Gas displaced }}\right)$ ze zbiorników terminala do wypełnienia komór ładunkowych statku podczas wyładunku LNG - lub ewentualnie dodatkowo pomniejszona o $E_{\text {Gas to ER }}$ (patrz poniżej) - zwykle [MMBTU],

$V_{L N G}-$ objętość nadanego lub odebranego gazu ciekłego $\left[\mathrm{m}^{3}\right]$, $D_{L N G}-$ gęstość gazu LNG $\left[\mathrm{kg} / \mathrm{m}^{3}\right]$,

$G C V_{L N G}$ - ciepło spalania LNG odniesione do jednostki masy cieczy (w języku ang. wielkość określana często jako gross calorific value - GCV) $[\mathrm{MJ} / \mathrm{kg}]$,

$E_{\text {Gas displaced }}$ - oznacza energię BOG - zwykle [MMBTU],

$E_{\text {Gas to ER }}$ - oznacza porcję energii zużytą do ewentualnego zasilania w LNG silników lub agregatów na statku na potrzeby pracy różnych systemów na statku (najczęściej podczas załadunku/rozładunku $E_{\text {Gaz to ER }}=0$ ) - zwykle [MMBTU].

Dla wyjaśnienia należy dodać, że wyrażenie porcji energii w jednostkach MMBTU wymaga użycia we wzorach obliczeniowych odpowiednich faktorów przeliczeniowych, 
uwzględniających zamianę jednostek z MJ na MMBTU (patrz równanie (2)).

W praktyce wszelkie obliczenia podczas rozładunku LNG są zwykle wykonywane podwójnie przez systemy rozliczeniowe CTMS (ang. custody transfer measurement system) na statku i na terminalu odbiorowym.

W handlu międzynarodowym LNG najczęściej używaną jednostką rozliczeniową jest MMBTU (million British thermal units, $\left.1 \mathrm{MMBTU}=10^{6} \mathrm{BTU}\right)$, pomimo że nie jest to jednostka układu SI. Wartość 1 BTU to ilość energii potrzebna do podniesienia temperatury jednego funta wody o jeden stopień Fahrenheita. Z powodu nieprecyzyjnej definicji tej jednostki, w związku ze zmianą ciepła właściwego wody w różnych temperaturach, jej wartość waha się od $1054 \mathrm{~J}$ do $1059 \mathrm{~J}$ (czyli od około 2,92 $\cdot 10^{-4} \mathrm{kWh}$ do około $\left.2,94 \cdot 10^{-4} \mathrm{kWh}\right)$.

Powyższe równanie (1) dotyczy sytuacji rozładunku LNG ze statku do zbiorników lądowych na terminalu odbiorowym. W przypadku załadunku na statek na terminalu załadunkowym w równaniu tym zmienia się tylko znak przed ostatnim członem równania, czyli zamiast , $-E_{\text {Gas to ER }}$ ”est ,,$+E_{\text {Gas to ER }}$.

$Z$ uwagi na fakt, że wartość energii BOG, czyli $E_{\text {Gas displaced, }}$, stanowi niewielką część całkowitej energii „netto”, najczęściej przyjmuje się, że opary BOG to czysty metan, który dodatkowo traktuje się jako gaz doskonały. Przy takim założeniu nie uwzględnia się wartości współczynnika ściśliwości dla oparów BOG. Podejście takie jest o tyle uzasadnione, że jak wcześniej wspomniano, energia w postaci BOG to stosunkowo niewielki człon w równaniu (1), a ciśnienia oparów BOG i tak niewiele przewyższają wartość ciśnienia atmosferycznego. Na wielu terminalach rozładunkowych w ogóle nie oblicza się członu $E_{\text {Gas displaced }}$, tylko przyjmuje się jego stałą wartość, na przykład na poziomie $0,3 \%$ [3]. Opisane powyżej uproszczenia w obliczaniu energii „netto” nie wprowadzają żadnego istotnego błędu, a bardzo ułatwiają praktyczne stosowanie równania (1).

Ponieważ do obliczenia finalnej wartości energii odpowiadającej danej partii rozładowanego LNG według równania (1) konieczna jest znajomość gęstości LNG, ciepła spalania LNG i ciepła spalania fazy gazowej BOG, które są zależne od przyjętych temperatur odniesienia $[3,8,9,10]$, dlatego kontrakty i procedury rozliczeniowe również odnosi się do konkretnych warunków odniesienia. Wartościami temperatur odniesienia, które często występują w kontraktach międzynarodowych, są $15^{\circ} \mathrm{C}$ i $60^{\circ} \mathrm{F}\left(15,56^{\circ} \mathrm{C}\right)$. Przykładowe pełne równanie rozliczeniowe, przy założeniu, że BOG stanowi czysty metan oraz że nie ma zużycia LNG na wewnętrzne potrzeby statku, dla przykładowej temperatury kontraktowej $15^{\circ} \mathrm{C}$ zaprezentowano poniżej jako równanie (2).

$$
\begin{aligned}
E & =\frac{1}{1055,056} \cdot\left(V_{L N G} \cdot D_{L N G} \cdot G C V_{L N G}-\right. \\
& \left.-V_{G} \cdot \frac{288,15}{273,15+T_{G}} \cdot \frac{p_{G}}{1,01325} \cdot 37,706\right)[\mathrm{MMBTU}]
\end{aligned}
$$

W równaniu (2) liczby i symbole oznaczają odpowiednio: 1055,056 - współczynnik przeliczeniowy dla energii wyrażonej w dżulach i przeliczanej na BTU dla temperatury referencyjnej $15^{\circ} \mathrm{C}$,

288,15 - temperatura referencyjna wynosząca $15^{\circ} \mathrm{C}[\mathrm{K}]$, 273,15 - temperatura $0^{\circ} \mathrm{C}[\mathrm{K}]$,

1,01325 - ciśnienie referencyjne fazy gazowej nad LNG w komorach ładunkowych statku [bar],

37,706 - ciepło spalania czystego metanu w warunkach referencyjnych $15^{\circ} \mathrm{C} / 15^{\circ} \mathrm{C} / 101,325 \mathrm{kPa}\left[\mathrm{MJ} / \mathrm{m}^{3}\right]$

$T_{G}$ - temperatura (z pomiaru) fazy gazowej nad LNG w komorach ładunkowych statku $[\mathrm{K}]$,

$p_{G}-$ ciśnienie absolutne (z pomiaru) fazy gazowej nad LNG w komorach ładunkowych statku [bar],

pozostałe oznaczenia jak w równaniu (1).

Powszechną praktyką jest, że na całym świecie stosuje się ujednolicony algorytm rozliczeniowy zgodny z przewodnikiem LNG Custody Transfer Handbook [3], który oprócz właściwego algorytmu (podanego w postaci równania (2)) precyzuje również dokładności dla mierzonych wartości pośrednich. Dokładności te to [3]:

- pomiar objętości LNG - poniżej $0,1 \%$,

- pomiar wysokości LNG w zbiornikach statku - poniżej $5 \mathrm{~mm}$,

- pomiar temperatury cieczy - poniżej $0,2^{\circ} \mathrm{C}$ dla zakresu od $-165^{\circ} \mathrm{C}$ do $-145^{\circ} \mathrm{C}$ (LNG) oraz poniżej $1,5^{\circ} \mathrm{C}$ dla zakresu od $-145^{\circ} \mathrm{C}$ do $+40^{\circ} \mathrm{C}$ (opary),

- pomiar ciśnienia (opary) - poniżej $1 \%$.

Systemy pomiarowe są całkowicie zautomatyzowane i nie stwarzają żadnych problemów praktycznych. Okresowo wszystkie urządzenia pomiarowe przechodzą kontrolę poprawności działania, co zostanie szczegółowo omówione w następnych artykułach niniejszej serii poświęconej problematyce LNG.

\section{Kontrola jakości LNG}

Do określenia ilości energii LNG w procesie rozliczeniowym ładunku LNG dostarczonego i rozładowanego w terminalu odbiorowym niezbędna jest dokładna znajomość jego składu. Istnieje zatem konieczność wykonywania 
bieżących analiz jakości LNG, na podstawie której wylicza się gęstość LNG i wszelkie wartości kaloryczne. Podobnie jak w przypadku kontroli jakości gazów ziemnych w infrastrukturze liniowej, tak i w przypadku morskich terminali LNG do kontroli jakości stosuje się metody chromatografii gazowej. Z uwagi na konieczność zapewnienia ciągłego nadzoru pomiarowo-analitycznego nad chromatografami gazowymi analizatory te lokuje się wyłączne na lądzie, czyli na terminalach, a nie na statkach. Podczas rozładunku LNG pobierane są jego próbki ciekłe, które się bezpośrednio regazyfikuje i analizie poddaje się odparowaną próbkę reprezentatywną LNG. Analizy na terminalach wykonuje się za pomocą procesowych chromatografów gazowych on-line lub w laboratoriach stacjonarnych.

Niezależnie od składu LNG zawartość ,„porcji” energii oblicza się według tego samego algorytmu, którego podstawa opisana jest w postaci równania (2). Oczywiście w kontraktach na ogół precyzuje się zakresy stężeń dla poszczególnych składników. Nie ma tutaj jednak żadnych reguł ogólnych i określa się je dla każdego kontraktu oddzielnie.

Wszelkie szczegóły dotyczące zasad próbkowania i wykonywania analiz jakościowych LNG w terminalach morskich będą przedmiotem kolejnych artykułów niniejszej serii poświęconej problematyce LNG.

\section{Podsumowanie}

Rozwój światowego handlu LNG trwa już od kilkudziesięciu lat. W artykule podano najważniejsze historyczne wydarzenia związane z samym skraplaniem gazów, w tym LNG, jak również wydarzenia dotyczące rozwoju światowego rynku i łańcucha dostaw LNG. Pomimo że problematyka LNG od dawna nie jest w Polsce nowa, to jednak dotychczas LNG nie było popularną formą paliwa i surowca. W najbliższej dekadzie wewnętrzny rynek LNG będzie się z całą pewnością w Polsce bardzo szybko rozwijał.

Od niedawna Polska jako kraj i niektóre polskie firmy gazownicze - np.: PGNiG SA, Gaz System SA, Polskie LNG SA - dołączyły do grupy państw i firm biorących udział w światowym handlu LNG transportowanym drogą morską. Zasady rozliczeń LNG w terminalach morskich są odmienne od stosowanych do rozliczeń gazów na infrastrukturze liniowej. $Z$ tego powodu podstawowym celem niniejszego artykułu było przedstawienie tych zasad i związanych z nimi metod pomiarowych. Szczegółowo podano, jakie pomiary wykonuje się na pokładach statków, a jakie na części lądowej terminali. Przedstawiono też dokładności pomiarowe wielkości pośrednich.

Rozliczenia LNG w terminalach morskich od dawna wykonuje się w jednostkach energii, co aktualnie jest powszechne w całym przemyśle gazowniczym w Polsce [7].

To pierwszy artykuł z planowanej serii mającej na celu przybliżenie problemów ogólnych dotyczących LNG, jak również kwestii związanych z szeroko pojętymi zagadnieniami kontroli jakości i rozliczeń LNG. W dalszych artykułach zostaną omówione szczegółowo zagadnienia związane z:

- procesami i metodami oczyszczania surowych gazów ziemnych przygotowywanych do skraplania,

- technologiami i instalacjami do skraplania gazów ziemnych,

- szczegółami dotyczącymi procesów rozładunkowych i pomiarów rozliczeniowych $\mathrm{LNG}$,

- szczegółami dotyczącymi pobierania próbek i kontroli jakości LNG,

- dokładnością i niepewnością metod określania ilości, wartości kalorycznych i energii dla partii LNG.

W kolejnych artykułach serii będą również przedstawione zagadnienia dotyczące nowych światowych trendów w zakresie pomiarów bezpośrednich LNG za pomocą przepływomierzy masowych dla cieczy kriogenicznych oraz spektroskopowych metod analitycznych opartych na spektroskopii widm Ramana do określania jakości LNG w terminalach morskich.

\section{Spis symboli:}

a.j.m - atomowa jednostka masy (odpowiada $1 / 12$ masy izotopu węgla ${ }^{12} \mathrm{C}$ )

BOG - gaz z odparowania LNG (ang. boil-off gas)

BTU - anglosaska jednostka energii (ang. British thermal units)

CTMS - system rozliczeniowy LNG (ang. custody transfer measuring system)

ER - komora silnika na statku (ang. engine room)

IMO - International Maritime Organization

LNG - skroplony gaz ziemny (ang. liquefied natural gas)

LPG - skroplona mieszanina propan-butan (ang. liquefied petroleum gas)

MTPA - milion ton na rok (million tones per annual)

MMBTU - milion BTU 
Prosimy cytować jako: Nafta-Gaz 2016, nr 2, s. 87-94, DOI: 10.18668/NG.2016.02.02

Artykuł nadesłano do Redakcji 3.08.2015 r. Zatwierdzono do druku 21.01.2016 r.

\section{Literatura}

[1] Encyklopedia LNG, Portal edukacyjny Lng.edu.pl, http://lng. edu.pl/pl/kategorie/encyklopedia-lng/ (dostęp: wrzesień 2014).

[2] Gas Technology Institute, http://www.gastechnology.org/About/Pages/default.aspx (dostęp: wrzesień 2014).

[3] GIIGNL: LNG Custody Transfer Handbook, 2011, ver. 3.11.

[4] GIIGNL: The LNG Industry in 2010.

[5] GIIGNL: The LNG Industry in 2013.

[6] International Gas Union: World LNG Report - 2014 Edition.

[7] Rosłonek G.: Rozliczanie paliw gazowych w jednostkach energii. Przemysł Gazowniczy 2014, vol. 42, nr 2.

[8] Rosłonek G.: Wewnątrzzakładowe procedury PGNiG SA obowiazujace podczas nadzoru metrologicznego nad rozliczeniowym systemem pomiarowym LNG. Część 1. Wersja 1.1. Analiza literaturowa. Opracowanie PGNiG SA O/CLPB, 201/B/ $\mathrm{PFC} / 2011$

\section{Akty prawne i normatywne}

[9] ISO 6578:1991 Refrigerated hydrocarbon liquids - Static measurement-Calculation procedure.
[10] ISO 6976:1995 Natural gas - Calculation of calorific values, density, relative density and Wobbe index from composition (wer. pol.: PN-EN ISO 6976:2008 Gaz ziemny - Obliczanie wartości kalorycznych, gęstości, gęstości względnej i liczby Wobbego na podstawie sktadu).

[11] PN-ISO 10976:2015 Schłodzone lekkie weglowodory płynne - Pomiary ładunków na pokładzie transportowców $L N G$

[12] Rozporzadzenie Ministra Gospodarki z dnia 2 lipca 2010 r. w sprawie szczegółowych warunków funkcjonowania systemu gazowego (Dz. U. Nr 133, poz. 891).
Grzegorz ROSŁONEK
Dyrektor Oddziału
Centralne Laboratorium Pomiarowo-Badawcze
Polskie Górnictwo Naftowe i Gazownictwo SA
ul. Kasprzaka 25B
01-224 Warszawa
E-mail: grzegorz.roslonek@pgnig.pl

\section{OFERTA}

\section{ZAKŁAD PRZESYŁANIA I DYSTRYBUCJI GAZU}

Zakres działania:

- badania laboratoryjne rur, kształtek, armatury z tworzyw sztucznych oraz armatury metalowej i powłok antykorozyjnych, prowadzone dla potrzeb certyfikacji i aprobat technicznych;

- ocena stopnia zagrożenia korozyjnego gazociągów stalowych oraz ocena stanu technicznego izolacji gazociągów stalowych metodami bezwykopowymi;

- ocena efektywności metod rekonstrukcji sieci dystrybucyjnych gazu;

- opracowanie projektów przepisów związanych z budową i użytkowaniem sieci gazowych;

- opracowanie lub opiniowanie projektów norm dotyczących sieci i instalacji gazowych;

- badania z zakresu współpracy ośrodka gruntowego z siecią gazową na terenach górniczych;

- $\quad$ prowadzenie specjalistycznego szkolenia kadr, głównie w zakresie budowy sieci gazowych z polietylenu;

- $\quad$ wspomaganie przemysłu we wdrażaniu nowych rozwiązań technicznych oraz opracowywanie ekspertyz i analiz;

- badania laboratoryjne metalowej armatury odcinającej do systemów i instalacji wodociągowych, baterii mechanicznych, natrysków i przewodów natryskowych oraz systemów rur wielowarstwowych do instalacji wody ciepłej i zimnej.

Kierownik: mgr inż. Piotr Szewczyk

Adres: ul. Bagrowa 1, 30-733 Kraków

Telefon: 12 617-74-42

Faks: 12 653-16-65

E-mail: piotr.szewczyk@inig.pl 